\title{
Fifteen-year time trends in energy and macronutrient intake in German children and adolescents: results of the DONALD study
}

\author{
Ute Alexy*, Wolfgang Sichert-Hellert and Mathilde Kersting \\ Research Institute of Child Nutrition (FKE), Dortmund, Germany \\ (Received 20 December 2000 - Revised 13 August 2001 - Accepted 27 January 2002)
}

\begin{abstract}
The DONALD study (Dortmund Nutritional and Anthropometric Longitudinally Designed study) gives the opportunity to evaluate long-term food and nutrient intake data on the basis of $3 \mathrm{~d}$ weighed dietary records of infants, children and adolescents since 1985. In this paper, we examine changes in energy and macronutrient intakes (protein, fat, saturated, mono- and polyunsaturated fatty acids, carbohydrates and added sugars) of 795 2-18-year-old subjects between 1985 and 2000 (4483 records). No significant changes in intakes of energy and of protein, polyunsaturated fatty acids and added sugars (as \% energy intake, E\%) were found. Fat intake decreased significantly in all age groups (between -0.20 and -0.26 E\%/year), as well as intake of saturated fatty acids (between -0.11 and $-0.14 \mathrm{E} \% / \mathrm{year}$ ) and monounsaturated fatty acids (between -0.07 and $-0.014 \mathrm{E} \% / y e a r$ ). This decline was compensated for by a significant increase in carbohydrate intake (between $+0 \cdot 18$ and $+0 \cdot 27 \mathrm{E} \% /$ year). The changes in macronutrient intake were mainly due to a decreased consumption of fats -oils (between $-0 \cdot 29$ and $-1.26 \mathrm{~g} /$ year) and meat-fish-eggs (between -0.21 and $-2.92 \mathrm{~g} /$ year), whereas consumption of bread-cereals (between $+0 \cdot 12$ and $+2.42 \mathrm{~g} /$ year) and potatoes-pasta-rice (between $+0 \cdot 15$ and $+2 \cdot 26$ g/year) increased slightly. However, since recommended fat intake and fatty acid composition was not reached at the end of the study period by far, further efforts will be necessary to improve macronutrient composition and to stabilize favourable dietary habits.
\end{abstract}

Children: Adolescents: Energy intake: Macronutrient intake: Time trend

Eating patterns are apparently changing over time. These trends are of interest since dietary habits, e.g. an imbalanced intake of macronutrients protein, fat and carbohydrate are associated with several chronic diseases which are responsible for high morbidity and mortality and thus costs of the public health systems in western societies (World Health Organization, 1990b). Based on the concept of prevention of atherosclerosis, several authorities recommend fat-reduced and fat-modified diets together with an increase in complex carbohydrates as a population-based preventive strategy starting as soon as in 'early childhood' (World Health Organization, 1990a) or from the age of 2 years (National Research Council, 1989; European Society for Pediatric Gastroentenology, Hepatology and Nutrition, Committee on Nutrition, 1994) while others call for specific dietary guidelines for young children (Canadian Pediatric Society and Health Canada, Joint Working Group, 1995). Dietary intake results from the last two decades show clear deviations from the recommended proportion of macronutrients in the diet of German (Deutsche Gesellschaft für Ernährung, 1994; Kersting et al. 1998a) and other European children and adolescents (Department of Health, 1989; Löwik et al. 1994; Strain et al. 1994; De Henauw et al. 1997). However, there is a lack of data concerning possible long-term changes of dietary habits. The DONALD study (Dortmund Nutritional and Anthropometric Longitudinally Designed study) gives the opportunity to evaluate long-term food and nutrient intake data on the basis of $3 \mathrm{~d}$ weighed dietary records of infants, children and adolescents since 1985. Here, we examine time trends in energy and macronutrient intakes (protein, fat, saturated, mono- and polyunsaturated fatty acids, carbohydrates and added sugars) of 2-18-year-old subjects between 1985 and 2000.

\section{Methods \\ Subjects}

The sample for this evaluation was taken from the DONALD study, details have been described elsewhere (Kersting et al. 1998b). In short, the DONALD study is

Abbreviations: E \%, \% energy.

* Corresponding author: Dr Ute Alexy, fax +49 231 711581, email alexy@fke-do.de 


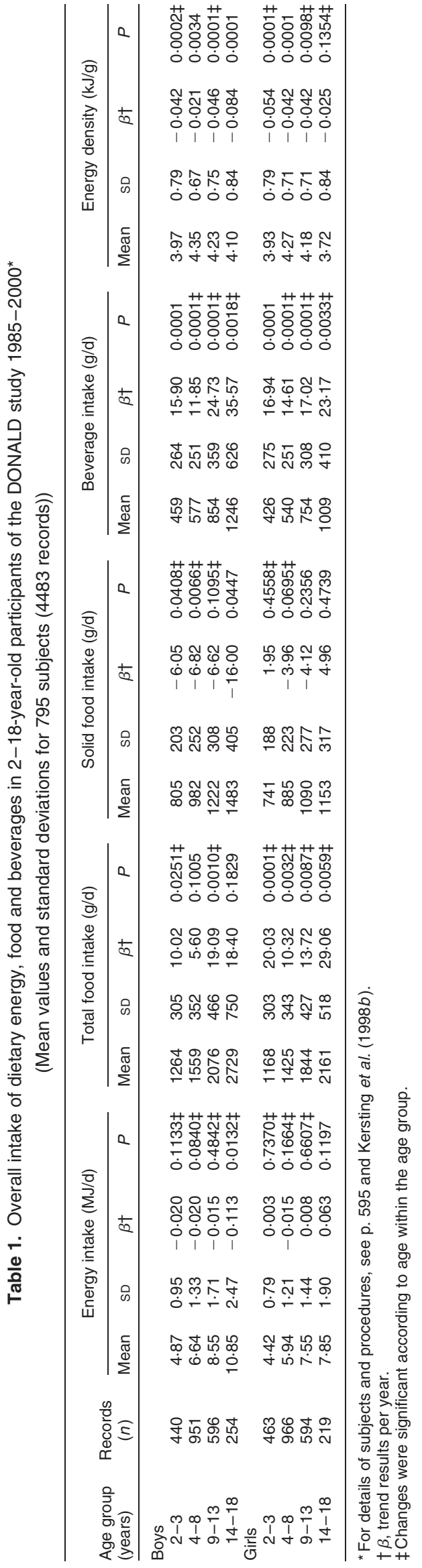

an observational study collecting detailed data on diet, metabolism, growth and development from healthy subjects between infancy and adulthood (once per year for subjects older than 2 years). The study started in the middle of 1985 with children and adolescents of different ages participating in exclusively anthropometric studies at our institute. Since then, yearly cohorts of about forty to fifty healthy infants have been enrolled. Mothers are recruited in maternity wards or are informed by other study participants. In the DONALD study sample upper social class families are over-represented. About $35 \%$ of the mothers and $45 \%$ of fathers have a grammar-school education and 221 and $39 \%$ respectively hold a university degree or a professional qualification (Kersting et al. 1998b). However, several evaluations showed no or only minor differences of dietary habits in our sample compared with the first nationwide German dietary survey from 1987-88 (Deutsche Gesellschaft für Ernährung, 1994).

\section{Nutrition survey}

Food consumption in the DONALD study is assessed with weighed dietary records as described elsewhere (Kersting et al. 1998b). Parents of the children or the older subjects themselves weighed and recorded all foods and fluids consumed, as well as leftovers, using electronic food scales $( \pm 1 \mathrm{~g})$ on three consecutive days. Product information from wrappers, cartons, etc. were kept and evaluated with the dietary records at home visits by our dietitians. Semi-quantitative recording (e.g. number of spoons, scoops) was allowed if weighing was not possible. However, in $75 \%$ of the completed records more then $90 \%$ of the food items were weighed. Weekdays $(71.5 \%)$ and weekend days $(28.5 \%)$ were proportionally distributed in the sample. To validate dietary recording, reported energy intake: predicted BMR ratio, according to Goldberg et al. (1991), was used. BMR was calculated using the equations of Schofield (1985) and height and weight of the individuals measured. The mean energy intake:BMR ratios of the sample of 1.43 (SD 0.24) ( $<6$ years old), 1.52 (SD 0.28) (males 6-18 years old) and 1.45 (SD 0.27) (females 6-18 years old) are in the recommended range of plausible dietary information according to Torun et al. (1996).

Energy and nutrient contents of common foods were taken from the German standard nutrient tables (Souci et al. 1994). Those of commercial food products were determined either by using the product labels or by simulating recipes from the ingredients listed. Energy and nutrient contents of all recorded food items were entered in a nutrient database 'LEBTAB' (3 660 different food items including composite dishes, Research Institute of Child Nutrition (FKE), Dortmund, Germany). For this analysis, dishes were broken down to basic food items according to food groups: 'beverages' included tap water, mineral water, coffee-tea and soft drinks. For further analysis, the following food groups were aggregated: 'bread-cereals' (including all sorts of bread and breakfast cereals, rolled oats), 'potatoes-pasta-rice', 'fruits-vegetables' (including fresh, frozen and tinned products and juices), 'milk-milk products' (including yoghurt, cheese), 'meat-fish-eggs' 
Table 2. Overall intake of macronutrients (as \% energy intake) in 2-18-year-old participants of the DONALD study 1985-2000*

(Mean values and standard deviations for 795 subjects (4483 records))

\begin{tabular}{|c|c|c|c|c|c|c|c|c|c|c|c|c|c|c|c|c|c|c|c|c|c|c|c|c|c|c|c|c|}
\hline \multirow{2}{*}{$\begin{array}{l}\text { Age } \\
\text { group } \\
\text { years }\end{array}$} & \multicolumn{4}{|c|}{ Protein $(E \%)$} & \multicolumn{4}{|c|}{ Total fat (E \%) } & \multicolumn{4}{|c|}{$\begin{array}{l}\text { Saturated fatty } \\
\text { acids }(\mathrm{E} \%)\end{array}$} & \multicolumn{4}{|c|}{$\begin{array}{l}\text { Monounsaturated fatty } \\
\text { acids }(\mathrm{E} \%)\end{array}$} & \multicolumn{4}{|c|}{$\begin{array}{l}\text { Polyunsaturated fatty acids } \\
(\mathrm{E} \%)\end{array}$} & \multicolumn{4}{|c|}{ Carbohydrates ( $E \%)$} & \multicolumn{4}{|c|}{ Added sugars ( $\mathrm{E} \%$ ) } \\
\hline & Mean & SD & $\beta \dagger$ & $P$ & Mean & SD & $\beta \dagger$ & $P$ & Mean & SD & $\beta \dagger$ & $P$ & Mean & SD & $\beta \dagger$ & $P$ & Mean & $\mathrm{SD}$ & $\beta \dagger$ & $P$ & Mean & SD & $\beta \dagger$ & $P$ & Mean & $\mathrm{SD}$ & $\beta \dagger$ & $P$ \\
\hline $2-3$ & $13 \cdot 1$ & $2 \cdot 0$ & 0.01 & $0.5779 \ddagger$ & 37.5 & 5.79 & -0.20 & 0.0003 & $17 \cdot 1$ & $3 \cdot 3$ & -0.11 & 0.0003 & $15 \cdot 6$ & $2 \cdot 7$ & -0.07 & 0.0040 & $4 \cdot 8$ & 1.7 & -0.01 & $0.4752 \ddagger$ & $49 \cdot 4$ & $6 \cdot 4$ & $0 \cdot 18$ & 0.0027 & $10 \cdot 6$ & $5 \cdot 2$ & -0.10 & $0.0585 \ddagger$ \\
\hline $4-8$ & $12 \cdot 6$ & 1.8 & 0.00 & 0.8071 & $37 \cdot 1$ & $5 \cdot 19$ & -0.26 & 0.0001 & 16.5 & $2 \cdot 8$ & -0.14 & 0.0001 & $15 \cdot 5$ & 2.5 & -0.11 & 0.0001 & $5 \cdot 1$ & 1.6 & -0.01 & 0.3790 & $50 \cdot 3$ & 5.7 & 0.26 & 0.0001 & $12 \cdot 8$ & 5.0 & 0.00 & $0.9479 \ddagger$ \\
\hline $9-13$ & $13 \cdot 0$ & $2 \cdot 0$ & -0.00 & $0.8956 \ddagger$ & $36 \cdot 8$ & 5.55 & -0.24 & 0.0001 & $16 \cdot 0$ & 3.0 & -0.12 & 0.0001 & $15 \cdot 3$ & $2 \cdot 7$ & -0.12 & 0.0001 & 5.5 & 1.7 & -0.00 & $0.9479 \ddagger$ & $50 \cdot 2$ & 5.9 & 0.24 & 0.0001 & $12 \cdot 9$ & $5 \cdot 2$ & 0.03 & 0.5978 \\
\hline $\begin{array}{l}14- \\
18\end{array}$ & 13.4 & $2 \cdot 1$ & -0.01 & $0.7202 \ddagger$ & 36.9 & 5.98 & -0.26 & 0.0011 & $16 \cdot 0$ & $3 \cdot 1$ & -0.13 & 0.0023 & $15 \cdot 4$ & $2 \cdot 8$ & -0.14 & 0.0001 & $5 \cdot 5$ & 1.9 & 0.01 & 0.6533 & $49 \cdot 7$ & $6 \cdot 2$ & 0.27 & 0.0010 & 12.4 & $5 \cdot 6$ & -0.01 & $0.8941 \neq$ \\
\hline
\end{tabular}

$E \%$ \% energy.

ibjects and procedures, see p. 595 and Kersting et al. (1998b).

sults per year.

Changes were significant according to age within the age group.

Table 3. Overall percentage of energy intake from fat from food groups in 2-18-year-old participants of the DONALD study 1985-2000* (Mean values and standard deviations for 795 subjects (4483 records))

\begin{tabular}{|c|c|c|c|c|c|c|c|c|c|c|c|c|c|c|c|c|}
\hline \multirow{2}{*}{$\begin{array}{l}\text { Age } \\
\text { group } \\
\text { (years) }\end{array}$} & \multicolumn{4}{|c|}{ Meat-fish-eggs ( $E \%$ from fat) } & \multicolumn{4}{|c|}{ Fats-oils ( $E \%$ from fat) } & \multicolumn{4}{|c|}{ Milk-milk products ( $E \%$ fat) } & \multicolumn{4}{|c|}{ Candy-cakes ( $E \%$ from fat) } \\
\hline & Mean & SD & $\beta \dagger$ & $P$ & Mean & SD & $\beta \dagger$ & $P$ & Mean & SD & $\beta \dagger$ & $P$ & Mean & SD & $\beta \dagger$ & $P$ \\
\hline \multicolumn{17}{|l|}{ Boys } \\
\hline $2-3$ & $9 \cdot 0$ & 5.5 & -0.01 & 0.9244 & 7.4 & 3.9 & -0.22 & 0.0001 & 11.9 & $5 \cdot 3$ & -0.10 & $0.1860 \ddagger$ & $5 \cdot 0$ & 3.7 & 0.04 & $0.4305 \ddagger$ \\
\hline $4-8$ & 9.2 & $5 \cdot 1$ & -0.12 & 0.0315 & $7 \cdot 8$ & 3.8 & -0.20 & 0.0001 & 9.8 & 4.2 & -0.07 & 0.1219 & $6 \cdot 0$ & 3.6 & 0.08 & 0.0316 \\
\hline $9-13$ & $9 \cdot 4$ & 5.4 & -0.21 & $0.0016 \ddagger$ & $7 \cdot 7$ & 3.8 & -0.25 & 0.0001 & $9 \cdot 2$ & 4.2 & 0.13 & 0.0128 & 5.9 & $3 \cdot 8$ & 0.03 & 0.5055 \\
\hline $14-18$ & $10 \cdot 3$ & $5 \cdot 7$ & 0.03 & 0.7866 & $7 \cdot 9$ & 4.5 & -0.27 & 0.0012 & $9 \cdot 3$ & $4 \cdot 1$ & 0.03 & 0.7191 & $5 \cdot 6$ & $4 \cdot 2$ & -0.08 & 0.2595 \\
\hline \multicolumn{17}{|l|}{ Girls } \\
\hline $2-3$ & $8 \cdot 8$ & $5 \cdot 2$ & 0.10 & 0.1646 & 7.5 & 4.2 & -0.21 & 0.0001 & $12 \cdot 2$ & $5 \cdot 2$ & -0.09 & $0.2059 \ddagger$ & $5 \cdot 2$ & $3 \cdot 3$ & 0.02 & $0.5758 \ddagger$ \\
\hline $4-8$ & 8.9 & $5 \cdot 1$ & -0.07 & 0.1780 & $8 \cdot 1$ & 3.7 & -0.26 & 0.0001 & 9.5 & 4.3 & -0.05 & 0.2220 & $6 \cdot 2$ & 3.8 & 0.02 & 0.5764 \\
\hline $9-13$ & 9.0 & $5 \cdot 4$ & -0.17 & 0.0135 & $7 \cdot 8$ & 3.9 & -0.23 & 0.0001 & $8 \cdot 8$ & 4.4 & 0.11 & 0.0449 & $6 \cdot 1$ & 4.0 & 0.01 & 0.7694 \\
\hline $14-18$ & $8 \cdot 8$ & 5.5 & -0.20 & 0.0648 & $7 \cdot 6$ & $4 \cdot 1$ & -0.24 & 0.0036 & $9 \cdot 4$ & 4.5 & $0 \cdot 10$ & 0.2745 & $5 \cdot 2$ & $4 \cdot 2$ & 0.01 & 0.8962 \\
\hline
\end{tabular}

E\%, \% energy

$\dagger \beta$, trend results per year.

$\ddagger$ Changes were significant according to age within the age group. 
Table 4. Overall intake of food groups ( $\mathrm{g} / \mathrm{d})$ in 2-18-year-old participants of the DONALD study 1985-2000*

(Mean values and standard deviations for 795 subjects (4483 records))

\begin{tabular}{|c|c|c|c|c|c|c|c|c|c|c|c|c|c|c|c|c|c|c|c|c|c|c|c|c|c|c|c|c|}
\hline & \multicolumn{4}{|c|}{ Bread-cereals $(\mathrm{g} / \mathrm{d})$} & \multicolumn{4}{|c|}{ Potatoes-pasta-rice (g/d) } & \multicolumn{4}{|c|}{ Fruits-vegetables (g/d) } & \multicolumn{4}{|c|}{ Milk-milk products $(\mathrm{g} / \mathrm{d})$} & \multicolumn{4}{|c|}{ Meat-fish-eggs (g/d) } & \multicolumn{4}{|c|}{ Fats-oils (g/d) } & \multicolumn{4}{|c|}{ Candy-cakes (g/d) } \\
\hline & Mean & SD & $\beta \dagger$ & $P$ & Mean & SD & $\beta \dagger$ & $P$ & Mean & SD & $\beta \dagger$ & $P$ & Mean & SD & $\beta \dagger$ & $P$ & Mean & SD & $\beta \dagger$ & $P$ & Mean & SD & $\beta \dagger$ & $P$ & Mean & SD & $\beta \dagger$ & $P$ \\
\hline \multicolumn{29}{|l|}{ Boys } \\
\hline $2-3$ & $71 \cdot 4$ & $32 \cdot 3$ & 0.48 & $0.2841 \ddagger$ & $62 \cdot 6$ & 35.0 & 0.48 & $0.3178 \ddagger$ & $172 \cdot 1$ & 104.4 & $-2 \cdot 10$ & 0.1710 & $341 \cdot 2$ & $178 \cdot 6$ & -4.22 & 0.0949 & $59 \cdot 3$ & 32.2 & -0.21 & $0.6301 \neq$ & $11 \cdot 3$ & 6.6 & -0.32 & $0.0003 \ddagger$ & $52 \cdot 3$ & $32 \cdot 3$ & -0.12 & $0.7849 \ddagger$ \\
\hline $4-8$ & $110 \cdot 6$ & $44 \cdot 1$ & 0.87 & $0.0581 \ddagger$ & 87.3 & $47 \cdot 1$ & 0.24 & $0.6034 \ddagger$ & 201.0 & $112 \cdot 2$ & $-4 \cdot 11$ & $0.0006 \ddagger$ & 359.8 & 183.2 & $-2 \cdot 17$ & $0.2658 \ddagger$ & 84.9 & $41 \cdot 1$ & -1.26 & $0.0048 \neq$ & $16 \cdot 4$ & 8.8 & -0.46 & $0.0001 \ddagger$ & 81.1 & 42.5 & -0.19 & $0.6621 \ddagger$ \\
\hline $9-13$ & 147.8 & 58.4 & $2 \cdot 19$ & $0.0024 \ddagger$ & 125.0 & 61.4 & 0.15 & $0.8473 \ddagger$ & 241.5 & 136.9 & -3.38 & 0.0597 & $419 \cdot 1$ & 241.9 & -0.91 & 0.7735 & $116 \cdot 1$ & 58.4 & -2.28 & $0.0016 \neq$ & $21 \cdot 3$ & 11.4 & -0.65 & $0.0001 \ddagger$ & 98.2 & 51.8 & -0.99 & $0.1102 \ddagger$ \\
\hline $\begin{array}{l}14-18 \\
\text { Sirls }\end{array}$ & 188.6 & $73 \cdot 2$ & 1.30 & 0.3491 & $150 \cdot 2$ & $79 \cdot 3$ & -1.07 & $0.4416 \neq$ & 281.6 & 154.0 & 0.09 & $0.9750 \ddagger$ & $493 \cdot 2$ & 278.9 & -7.73 & 0.1611 & 158.2 & 68.4 & -2.92 & $0.0235 \ddagger$ & 28.6 & 19.6 & -1.26 & $0.0008 \ddagger$ & 111.8 & 70.8 & -2.46 & 0.0571 \\
\hline \multicolumn{29}{|l|}{ Girls } \\
\hline $\begin{array}{l}2-3 \\
4-8\end{array}$ & 61.4 & 23.9 & 0.12 & $0.6902 \ddagger$ & 55.0 & 28.1 & 0.81 & $0.0310 \neq$ & 168.0 & 91.1 & 1.45 & 0.2252 & 310.7 & 161.5 & -0.91 & $0.6841 \neq$ & 55.1 & 29.5 & 0.23 & $0.5586 \ddagger$ & 10.4 & 5.9 & -0.29 & $0.0001 \ddagger$ & 49.5 & $28 \cdot 3$ & -0.08 & $0.8234 \ddagger$ \\
\hline $\begin{array}{l}4-8 \\
9-13\end{array}$ & 94.3 & $36 \cdot 2$ & 0.98 & $0.0050 \ddagger$ & 80.5 & 44.2 & 0.73 & $0.0983 \ddagger$ & 202.0 & $105 \cdot 1$ & -1.29 & $0.2444 \ddagger$ & 304.2 & 165.1 & -2.72 & $0.1074 \ddagger$ & 74.2 & 35.7 & -0.80 & $0.0373 \neq$ & $15 \cdot 3$ & 7.8 & -0.47 & $0.0001 \neq$ & 76.9 & 39.5 & 0.06 & $0.8728 \ddagger$ \\
\hline $14-18$ & $\begin{array}{l}129.6 \\
117.1\end{array}$ & 49.7 & 1.10 & $0.0745 \ddagger$ & 110.4 & 58.2 & 0.53 & $0.4314 \ddagger$ & 261.9 & $\begin{array}{l}143.9 \\
167\end{array}$ & -4.83 & $0.0071 \neq$ & $320 \cdot 3$ & 184.6 & 1.24 & 0.5993 & $100 \cdot 2$ & $53 \cdot 3$ & -1.98 & $0.0033 \neq$ & $19 \cdot 0$ & 10.4 & -0.46 & $0.0001 \ddagger$ & 92.8 & $50 \cdot 8$ & 0.17 & 0.7822 \\
\hline & 137.1 & & 2.42 & $0.0 / 46$ & 128.6 & 13.8 & 2.26 & 0.1317 & $305 \cdot 1$ & $10 \% \cdot 6$ & 3.65 & 0.2991 & $312 \cdot 4$ & 183.9 & 0.83 & 0.8315 & 107.8 & $56 \cdot 0$ & -2.00 & 0.0833 & 19.6 & 12.4 & -0.29 & 0.2438 & 80.0 & 59.4 & -0.07 & 0.9558 \\
\hline
\end{tabular}

${ }^{*}$ For details of subjects and procedures, see p. 595 and Kersting et al. (1998b).

$\dagger \beta$, trend results per group.

$\ddagger$ Changes were significant according to age within the age group.

Table 5. Overall percentage of energy intake from carbohydrates from food groups in 2-18-year-old participants of the DONALD study 1985-2000* (Mean values and standard deviations for 795 subjects (4483 record))

\begin{tabular}{|c|c|c|c|c|c|c|c|c|c|c|c|c|c|c|c|c|}
\hline \multirow{2}{*}{ Age group (years) } & \multicolumn{4}{|c|}{ Bread-cereals ( $\mathrm{E} \%$ as $\mathrm{CHO}$ ) } & \multicolumn{4}{|c|}{ Potatoes-pasta-rice (E \% as $\mathrm{CHO})$} & \multicolumn{4}{|c|}{ Fruits-vegetables ( $\mathrm{E} \%$ as $\mathrm{CHO}$ ) } & \multicolumn{4}{|c|}{ Candy-cakes (E \% as $\mathrm{CHO})$} \\
\hline & Mean & SD & $\beta \dagger$ & $P$ & Mean & SD & $\beta \dagger$ & $P$ & Mean & SD & $\beta \dagger$ & $P$ & Mean & SD & $\beta$ & $P$ \\
\hline \multicolumn{17}{|l|}{ Boys } \\
\hline $2-3$ & $12 \cdot 6$ & 5.4 & 0.08 & $0.2990 \ddagger$ & $5 \cdot 0$ & 2.9 & 0.09 & 0.0293 & $6 \cdot 6$ & $4 \cdot 1$ & -0.04 & $0.5001 \ddagger$ & 9.8 & $5 \cdot 1$ & -0.04 & $0.5951 \ddagger$ \\
\hline $4-8$ & $14 \cdot 6$ & $5 \cdot 1$ & 0.18 & $0.0008 \ddagger$ & $5 \cdot 4$ & 2.9 & 0.09 & $0.0018 \ddagger$ & 5.4 & 3.4 & -0.12 & $0.0007 \ddagger$ & 11.0 & 4.8 & -0.04 & 0.4846 \\
\hline $9-13$ & $15 \cdot 4$ & $5 \cdot 5$ & 0.31 & 0.0001 & $6 \cdot 1$ & $3 \cdot 1$ & 0.04 & 0.3037 & 4.8 & 3.2 & $-0 \cdot 10$ & 0.0124 & $10 \cdot 3$ & 4.8 & -0.15 & 0.0110 \\
\hline $14-18$ & $15 \cdot 5$ & 5.4 & 0.31 & 0.0006 & $5 \cdot 8$ & 3.1 & 0.04 & 0.4933 & 4.2 & $2 \cdot 7$ & 0.04 & $0.4346 \ddagger$ & 9.5 & $5 \cdot 3$ & -0.20 & $0.0455 \ddagger$ \\
\hline \multicolumn{17}{|l|}{ Girls } \\
\hline $2-3$ & $12 \cdot 0$ & 4.8 & 0.05 & 0.4053 & 4.9 & 2.5 & 0.08 & 0.0157 & $7 \cdot 0$ & 4.4 & 0.03 & $0.5815 \ddagger$ & $10 \cdot 1$ & $5 \cdot 1$ & -0.07 & 0.3185 \\
\hline $4-8$ & 13.9 & 4.8 & 0.19 & 0.0001 & 5.5 & 3.2 & 0.09 & 0.0027 & $6 \cdot 0$ & 3.5 & -0.05 & 0.1524 & 11.4 & $5 \cdot 1$ & -0.01 & 0.8629 \\
\hline $9-13$ & $15 \cdot 0$ & 5.4 & 0.20 & 0.0035 & $6 \cdot 2$ & 3.5 & 0.09 & 0.0376 & $5 \cdot 8$ & 3.4 & -0.13 & 0.0013 & $10 \cdot 7$ & $5 \cdot 2$ & -0.01 & $0.8303 \ddagger$ \\
\hline $14-18$ & 14.8 & $5 \cdot 8$ & 0.15 & 0.2063 & $7 \cdot 0$ & $4 \cdot 1$ & 0.06 & 0.5089 & $6 \cdot 5$ & 4.5 & -0.03 & 0.7316 & 8.9 & $5 \cdot 7$ & -0.09 & $0.4555^{\top}$ \\
\hline
\end{tabular}

$\mathrm{E} \%$ \% energy; $\mathrm{CHO}$, carbohydrate.

* For details of subjects and procedures, see p. 595 and Kersting et al. (1998b).

$\dagger \beta$, trend results per year.
$\ddagger$ Changes were significant according to age within the age group. 
(including sausages, tinned meat and fish), 'fats-oils' (including butter, margarine, plant oils, lard and tallow), 'candy-cakes' (including chocolate, sweetmeats, bars and biscuits). Total food intake ( $\mathrm{g} / \mathrm{d})$ was defined as the sum of all recorded foods and beverages. The difference between total food intake and beverage intake was named as solid food. Energy density was calculated as the energy content $(\mathrm{kJ})$ divided by the food intake $(\mathrm{g})$. Added sugars were defined as sum of added mono-, diand oligosaccharides. Fatty acids were summarized to the subgroups saturated, monounsaturated and polyunsaturated fatty acids.

\section{Anthropometry}

For body-weight measurements (to the nearest $0.1 \mathrm{~kg}$ ) an electronic scale (Seca 753 E Seca, Hamburg, Germany) was used. Body height $(\mathrm{cm})$ was measured using a digital telescopic wall-mounted stadiometer (Harpenden, Rapperswil, Switzerland). For assessment of relative weight, the BMI was calculated as $\mathrm{kg} / \mathrm{m}^{2}$. For definition of overweight and obesity we used age- and sex- specific cut-off points for BMI based on pooled international data (Cole et al. 2000).

\section{Statistical analyses}

$\mathrm{SAS} \AA$ procedures (version 6.12; Statistical Analysis Systems, Cary, NC, USA) were used for data analysis. Energy, nutrient and food intakes were calculated as individual means of the three recorded days. Results are presented as mean values and standard deviations. To analyse the influence of time (trend) on the outcome variables a mixed linear model was used, in which the means of the data, the covariance structure, and the effect of repeated measurements were measured (PROC MIXED). An exponential structure of covariance was specified to consider correlation of repeated measurements dependent on the absolute time interval of repeated measurements within the same subject. Trend results were noted (see $\beta$ in Tables 1-6): increase (+), decrease (-). Trends in prevalence of overweight and obesity were tested with Cochran-Armitage Test.

\section{Ethical considerations}

The DONALD study is exclusively observational, nonintervening, and non-invasive as approved by the International Scientific Committee of the Research Institute of Child Nutrition.

\section{Results \\ Subjects}

Between July 1985 and July 2000 a total of 4483 records from 795 subjects (386 males, 409 females) aged 2-18 years were collected and evaluated. On average 5.6 records per participant were available. Between 144 and 372 subjects participated per year as presented as additional information in Fig. 1. Mean age ranged from $6 \cdot 7$ (SD 4.3) to $9 \cdot 2$ (SD 4.2) years per study year.

The trend analysis in the total sample showed that age had a remarkable effect. Therefore, four age groups were analysed separately $(2-3,4-8,9-13$ and $14-18$ years according to the US Institute of Medicine, 2000). Energy and food group intakes as well as anthropometric data showed differing results in boys and girls; therefore results were given by sex. In macronutrient intakes expressed as $\%$ energy intake $(\mathrm{E} \%)$ there were no significant differences according to sex.

\section{Energy and food intakes}

With age, energy intake $(\mathrm{MJ} / \mathrm{d})$ and total food intake increased 2.2-fold in boys and 1.8-fold in girls (Table 1). Percentage of beverages in the total weight of food intake increased with age from 36 to $45 \%$ in boys and from 36 to $47 \%$ in girls. Energy density ranged between $3.72 \mathrm{~kJ} / \mathrm{g}$ in $14-18$-year-old girls and $4.35 \mathrm{~kJ} / \mathrm{g}$ in $4-8$ year-old boys.

In the 15-year period of the DONALD study, we found no significant change in energy intake with the exception

Table 6. Overall body weight, body height and BMI in 2-18-year-old participants of the DONALD study 1985-2000* (Mean values and standard deviations for 795 subjects (4483 records))

\begin{tabular}{|c|c|c|c|c|c|c|c|c|c|c|c|c|}
\hline \multirow[b]{2}{*}{ Age group (years) } & \multicolumn{4}{|c|}{ Body weight (kg) } & \multicolumn{4}{|c|}{ Body height $(\mathrm{cm})$} & \multicolumn{4}{|c|}{ BMI $\left(\mathrm{kg} / \mathrm{m}^{2}\right)$} \\
\hline & Mean & SD & $\beta \dagger$ & $P$ & Mean & SD & $\beta \dagger$ & $P$ & Mean & SD & $\beta \dagger$ & $P$ \\
\hline \multicolumn{13}{|l|}{ Boys } \\
\hline $2-3$ & 14.9 & $2 \cdot 2$ & 0.00 & $0.9048 \ddagger$ & 96 & 6 & 0.05 & $0.3719 \ddagger$ & $16 \cdot 1$ & 1.1 & -0.016 & $0.3323 \ddagger$ \\
\hline $4-8$ & $23 \cdot 3$ & $5 \cdot 5$ & -0.04 & $0.4042 \ddagger$ & 120 & 11 & -0.00 & $0.9686 \ddagger$ & $15 \cdot 9$ & 1.5 & -0.022 & $0.2344 \ddagger$ \\
\hline $9-13$ & $40 \cdot 1$ & $10 \cdot 0$ & 0.16 & $0.1363 \ddagger$ & 149 & 11 & $0 \cdot 16$ & $0.1132 \ddagger$ & $17 \cdot 9$ & $2 \cdot 6$ & 0.030 & $0.3892 \ddagger$ \\
\hline $14-18$ & $64 \cdot 3$ & 11.4 & 0.02 & $0.9201 \ddagger$ & 176 & 8 & $0 \cdot 18$ & $0.2613 \ddagger$ & $20 \cdot 8$ & $2 \cdot 7$ & -0.043 & $0.4200 \ddagger$ \\
\hline \multicolumn{13}{|l|}{ Girls } \\
\hline $2-3$ & $14 \cdot 2$ & $2 \cdot 2$ & -0.02 & $0.3712 \ddagger$ & 94 & 6 & -0.00 & $0.9712 \ddagger$ & $15 \cdot 8$ & 1.3 & -0.023 & $0.2108 \ddagger$ \\
\hline $4-8$ & $22 \cdot 8$ & $5 \cdot 8$ & -0.06 & $0.1821 \ddagger$ & 119 & 11 & $-0 \cdot 16$ & $0.0053 \ddagger$ & $15 \cdot 9$ & $1 \cdot 8$ & -0.010 & $0.6544 \ddagger$ \\
\hline $9-13$ & $41 \cdot 1$ & $11 \cdot 3$ & 0.28 & $0.0226 \ddagger$ & 149 & 11 & 0.17 & $0.0806 \ddagger$ & $18 \cdot 1$ & 3.0 & 0.080 & $0.0498 \ddagger$ \\
\hline $14-18$ & $60 \cdot 7$ & $10 \cdot 4$ & 0.43 & $0.0761 \ddagger$ & 168 & 7 & 0.21 & $0.1084 \ddagger$ & $21 \cdot 3$ & 2.9 & 0.097 & $0.1992 \ddagger$ \\
\hline
\end{tabular}

* For details of subjects and procedures, see p. 595 and Kersting et al. (1998b).

$\dagger \beta$, trend results per group.

$\ddagger$ Changes were significant according to age within the age group. 


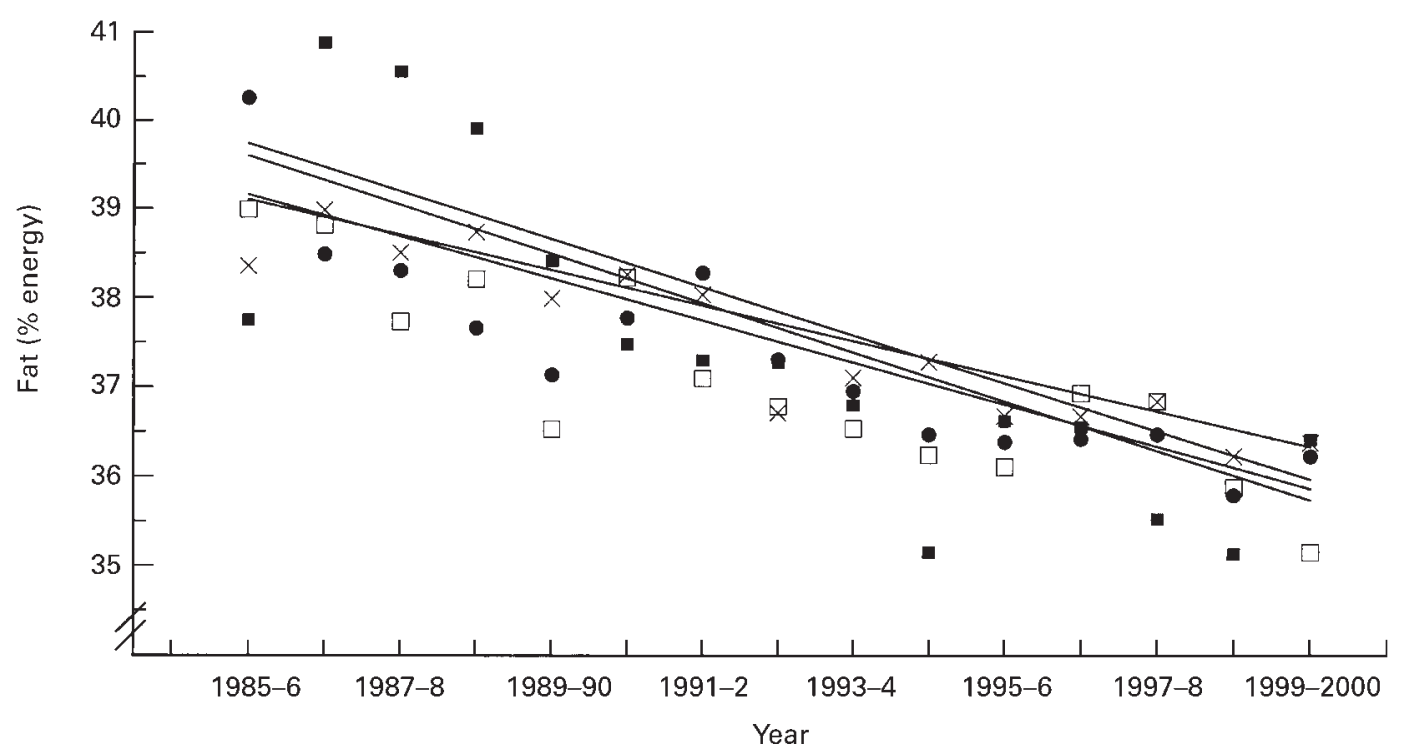

Fig. 1. Intake of fat in 12-18-year-old participants of the DONALD study. $\times, 2-3$-year-olds, •, 4-8-year-olds; $\square, 9-13$-year-olds; $\mathbf{\square}, 14-18$ year-olds; - trends. For details of subjects and procedures, see p. 595 and Kersting et al. (1998b). The numbers of subjects were (male, female): 1985-6 70, 76 and 90, 84; 1987-8 101, 85 and 113, 110; 1989-90 139, 131 and 141, 136; 1991-2 157, 146 and 167, 159, 1993-4 174, 176 and 184, 179; 1995-6 165, 184 and 185, 196; 1997-8 189, 188 and 191, 209; 1999-2000 169, 189.

of 14-18-year-old boys, although total food intake increased in all age and sex groups between $+5.6 \mathrm{~g} / \mathrm{d}$ per year and $+29.06 \mathrm{~g} / \mathrm{d}$ per year, due to a significant increase in beverage consumption (between $+11.85 \mathrm{~g} / \mathrm{d}$ per year and $+35.57 \mathrm{~g} / \mathrm{d}$ per year), whereas solid food intake decreased slightly in most age-sex groups. The increase in beverage consumption led to a mostly significant decrease in energy density of between $-0.025 \mathrm{~kJ} / \mathrm{g}$ per year and $-0.084 \mathrm{~kJ} / \mathrm{g}$ per year.

\section{Macronutrient and food group intakes}

Overall protein intake ranged between 12.6 and $13.4 \mathrm{E} \%$ without significant time trends (Table 2). Overall fat intake ranged between 36.9 and $37.5 \mathrm{E} \%$ and decreased significantly in all age groups (between -0.20 and $-0.26 \mathrm{E} \%$ /year). This resulted in a decrease in fat intake from $\geq 37.8 \mathrm{E} \%$ in $1985-86$ to $\leq 36.4 \mathrm{E} \%$ in 1999-2000 (Fig. 1). This decrease was due to a significant

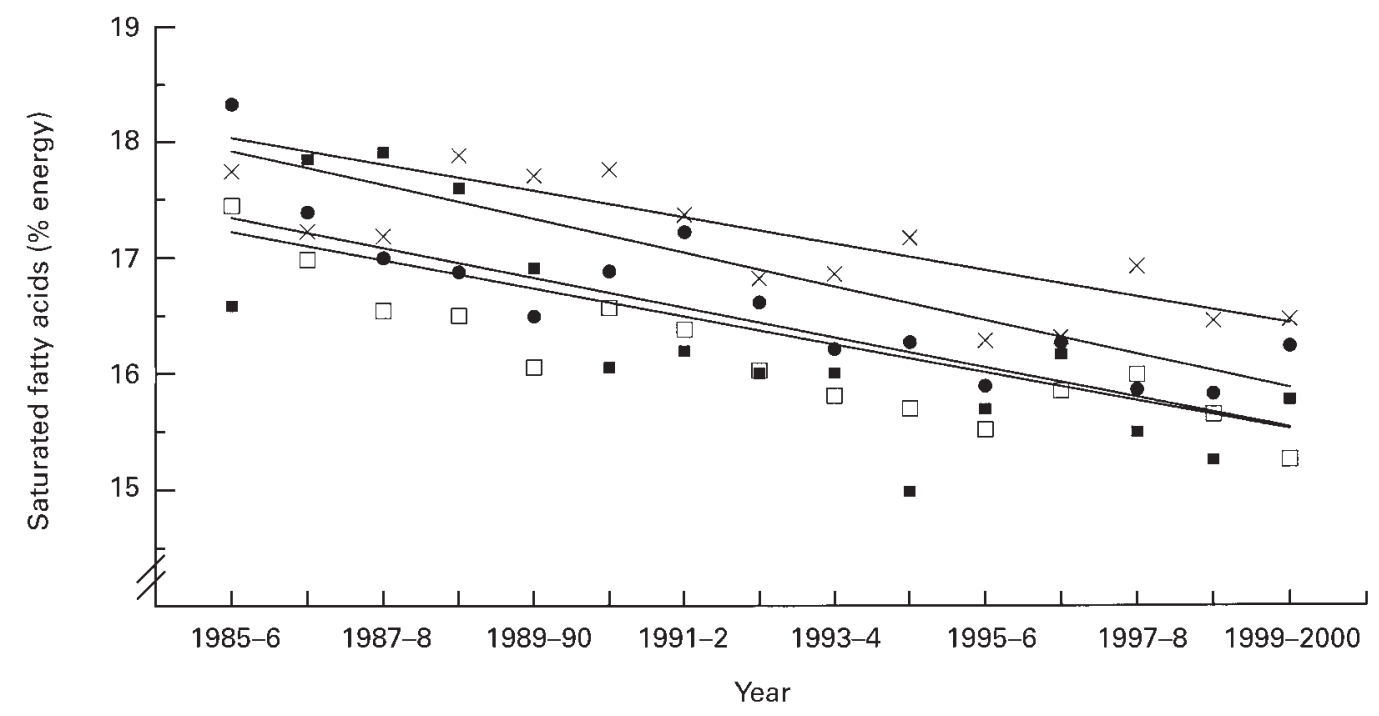

Fig. 2. Intake of saturated fatty acids in 12-18-year-old participants of the DONALD study. $\times, 2-3$-year-olds, •, 4-8-year-olds; $\square$, 9-13year-olds; $\mathbf{0}, 14-18$-year-olds; - trends. For details of subjects and procedures, see p. 595 and Kersting et al. (1998b). The numbers of subjects were (male, female): 1985-6 70, 76 and 90, 84; 1987-8 101, 85 and 113, 110; 1989-90 139, 131 and 141, 136; 1991-2 157, 146 and 167, 159, 1993-4 174, 176 and 184, 179; 1995-6 165,184 and 185, 196; 1997-8 189, 188 and 191, 209; 1999-2000 $169,189$. 


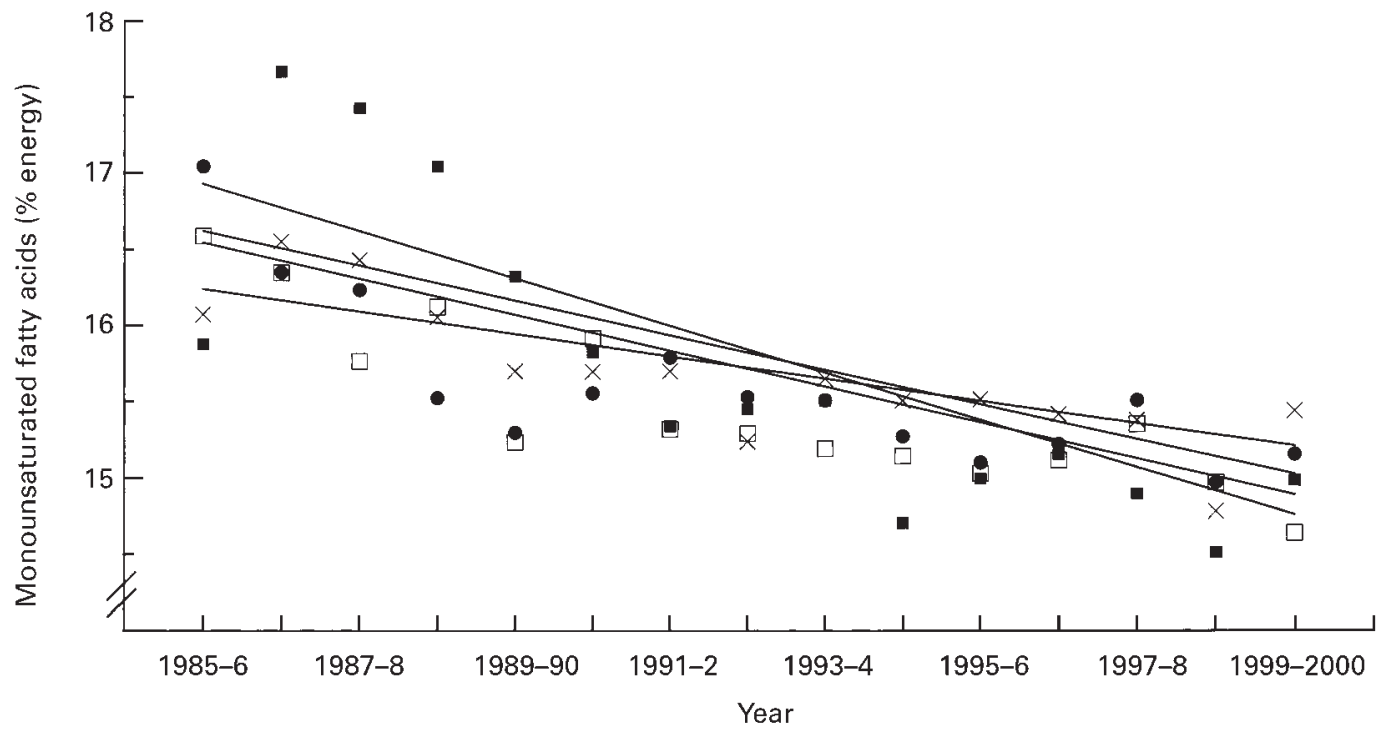

Fig. 3. Intake of monounsaturated fatty acids in 12-18-year-old participants of the DONALD study. $\times, 2-3$-year-olds, $\bullet, 4-8$-year-olds; $\square$, 913-year-olds; $\mathbf{\square}, 14-18$-year-olds; - , trends. For details of subjects and procedures, see p. 595 and Kersting et al. (1998b). The numbers of subjects were (male, female): 1985-6 70, 76 and 90, 84; 1987-8 101, 85 and 113, 110; 1989-90 139, 131 and 141, 136; 1991-2 157, 146 and 167, 159, 1993-4 174, 176 and 184, 179; 1995-6 165, 184 and 185, 196; 1997-8 189, 188 and 191, 209; 1999-2000 $169,189$.

decrease in saturated fatty acids (Fig. 2) (between $-0 \cdot 11$ and $-0 \cdot 14 \mathrm{E} \% / \mathrm{year})$ and monounsaturated fatty acids (Fig. 3) (between -0.07 and $-0.014 \mathrm{E} \% / y e a r)$, whereas intake of polyunsaturated fatty acids (Fig. 4) (E\%) remained constant over time. The decline in fat intake (E \%) was compensated for by a significant increase in carbohydrate intake (Fig. 4) (between $+0 \cdot 18$ and $+0 \cdot 27$ E\%/year). Thus, from 1985-86 to 1999-2000, carbohydrate intake increased from $\leq 49.9 \mathrm{E} \%$ to $\geq 50.5 \mathrm{E} \%$ (Fig. 1). Intake of added sugars remained constant over time (overall between 10.6 and $12.9 \mathrm{E} \%$ ).
The analysis of food groups showed a significant decline of fat intake from fats-oils (between -0.20 and -0.27 E\%/year) in all age-sex groups and from meat-fisheggs in some age-sex groups (Table 3). Overall intake $(\mathrm{g} / \mathrm{d})$ of fats-oils (between -0.29 and $-1.26 \mathrm{~g} /$ year) as well as meat-fish-eggs (between -0.21 and $-2.92 \mathrm{~g} /$ year) decreased significantly in most age-sex groups (Table 4). Fat intake from milk-milk products (E\%) as well as overall intake of this food group showed no significant trends with the exception of 9-13-year-olds. Fat intake from candy-cakes increased slightly in most age-

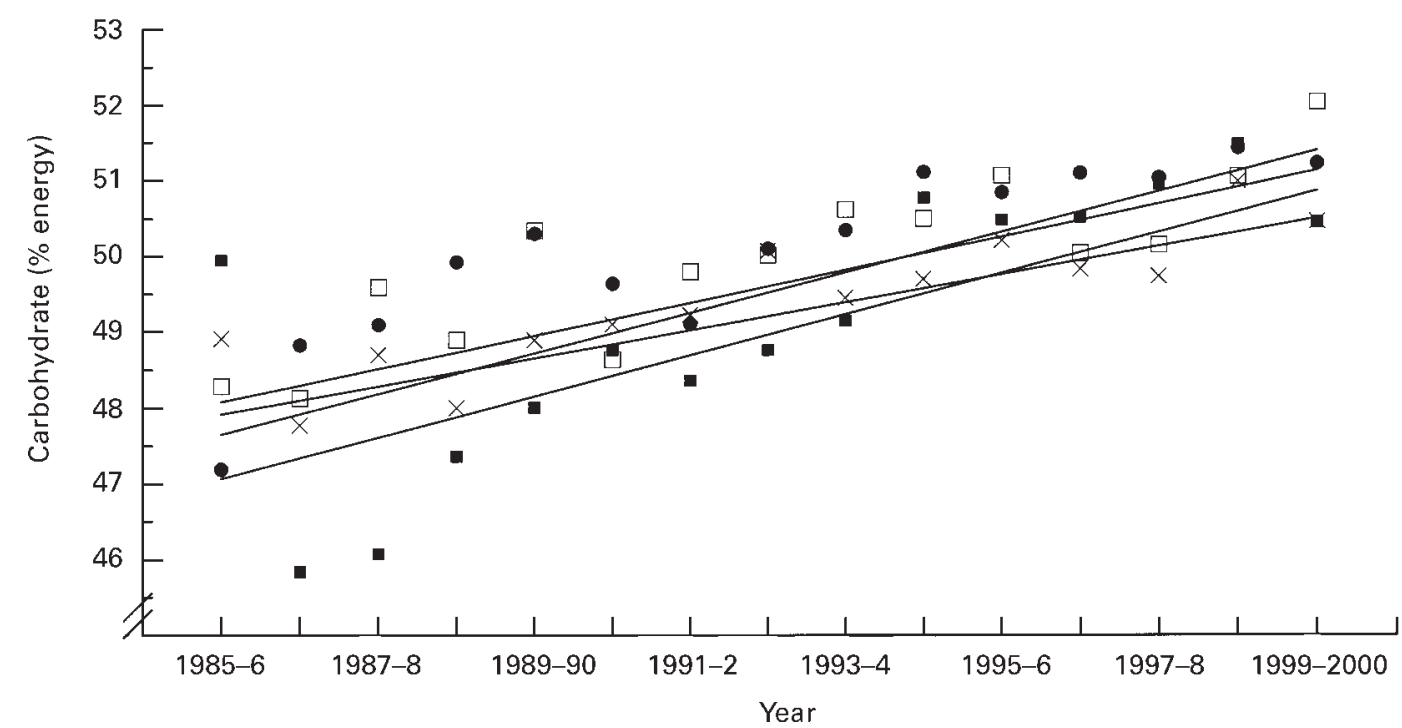

Fig. 4. Intake of carbohydrate in 12-18-year-old participants of the DONALD study. $\times, 2-3$-year-olds, $\bullet, 4-8$-year-olds; $\square$, 9-13-year-olds; 口, 14-18-year-olds; - trends. For details of subjects and procedures, see p. 595 and Kersting et al. (1998b). The numbers of subjects were (male, female): 1985-6 70, 76 and 90, 84; 1987-8 101, 85 and 113, 110; 1989-90 139, 131 and 141, 136; 1991-2 157, 146 and 167, 159, 1993-4 174, 176 and 184, 179; 1995-6 165, 184 and 185, 196; 1997-8 189, 188 and 191, 209; 1999-2000 169, 189. 
sex groups, but changes were mostly not significant (Table 3). Overall intake of this food group did not change over time (Table 4).

The increase in carbohydrate intake (E \%) during the 15year period was mainly due to an increase in carbohydrates from bread-cereals (between $+0 \cdot 05$ and $+0 \cdot 31$ E\%/year) and potatoes-pasta-rice (between +0.04 and $+0.09 \mathrm{E} \% /$ year), significant in most age-sex groups (Table 5). Overall intake of these food groups increased slightly, but increase was not significant. Carbohydrate intake from fruits-vegetables and candy-cakes decreased slightly (Table 5), but overall intake remained stable (Table 4). No significant time trends were found in intake of carbohydrates from milk-milk products and beverages (results not shown).

\section{Anthropometry}

Prevalence of overweight in each year ranged between 6.7 and $12.8 \%$ of subjects, and between 0.7 and $2.4 \%$ of subjects were obese. Over the study period, we found no trends in the prevalences of overweight and obesity (results not shown). Body weight and BMI also remained constant, with the exception of a slight increase of body weight $(+0.28 \mathrm{~kg} /$ year $)$ and BMI $\left(+0.080 \mathrm{~kg} / \mathrm{m}^{2}\right.$ year $)$ in $9-13-$ year-old girls (Table 6). Changes in body height were also not significant with the exception of $4-8$ year-old girls $(-1.6 \mathrm{~mm} /$ year $)$.

\section{Discussion}

The 15-year time trend analysis of energy and macronutrient intake in 2-18-year-old German children and adolescents of the DONALD study leads to the following main results: (1) energy intake remained constant over the study period; (2) total food intake increased as a result of an increased consumption of beverages; (3) macronutrient pattern improved slightly with regard to a decrease in fat intake $(\mathrm{E} \%)$ compensated for by an increase in carbohydrate intake $(\mathrm{E} \%)$, but dietary recommendations of $30-35 \mathrm{E} \%$ from fat were not reached in the end; (4) the improvements of macronutrient patterns resulted mainly from a reduced intake of fats-oils and meat-fish-eggs and a slightly increased intake of bread-cereals and potatoes-pasta-rice.

In total, these results are in accordance with those found in other surveys examining trends in nutrient and food intakes. Findings from German household surveys (Deutsche Gesellschaft für Ernährung, 2000) also confirm the trends observed in the DONALD study.

\section{Energy intake}

The energy intake of our sample was within the ranges of international results for energy requirements for moderate physical activity in the 2-8-year-old groups, for light physical activity in the 9-13-year-old groups and 14-18year-old boys, and below the level for light physical activity in the 14-18-year-old girls (Torun et al. 1996).

Physical activity was not assessed in the present study nor are there results from other German children and adolescents. However, surveys in other countries indicate that physical activity seems to decline steadily from childhood through adolescence to adulthood in particular in females (Oja, 1997). This can explain the reduction of energy intake compared with requirements with increasing age. In addition, a recent analysis of the DONALD study showed a trend to under-reporting in adolescent girls (Sichert-Hellert et al. 1998). This effect can be responsible for the low energy intake in this age-sex group.

In the 15-year period of the DONALD study energy intake remained stable over time as found in 10-year-old US children between 1973 and 1994 (Nicklas et al. 2001) and in Canadian female students between 1986 and 1991 (Barr, 1993). In contrast, Adamson et al. (1992) found a decline in energy intake in 11-12-yearold Northumbrian (UK) children between 1980 and 1990 in boys but not in girls.

There are no existing data on time trends in energy intake of German children and adolescents, but for German adult men the Monica Project Augsburg showed a slight decrease in the mean daily energy intake between 1984-85 and 1994-95 (Winkler et al. 2000).

The observed increase in beverage consumption agrees with findings from US children and adolescents as pointed out by Sichert-Hellert et al. (2001). This increase was mainly due to an increased consumption of tap water, mineral water and fruit juice and explains the lack of effects on total energy intake.

Our results do not confirm the stated increase in energy density from childhood to puberty as found by MartiHenneberg et al. (1999). These authors only considered food items that contained energy, whereas we included also tap and mineral water.

In the DONALD study the reported total food intake increased during the study period, indicating no trend to under-report food intake with longer study participation, although some participants repeated the recording up to fifteen times during the study period. In addition, a recent analysis of the DONALD study found no effects of under-reporting on the proportions of macronutrient intake (Sichert-Hellert et al. 1998).

\section{Macronutrient and food group intake}

At the beginning of the DONALD study in 1985, the recommended fat intake (30-35 E\%) was exceeded by far. After 15 years, despite the significant reduction, fat intake (E \%) only reached the upper recommended boundaries, so that a further reduction is still necessary. The same is true for the intake of saturated fatty acids $(\mathrm{E} \%)$. The recommended intake of carbohydrates $(>50 \mathrm{E} \%)$ was approximately reached in the last third of the observation period due to an increased consumption of breadcereals and potatoes-pasta-rice. Since added sugars remained stable, the quality of carbohydrate intake improved.

At present, measured longitudinal data of food and nutrient intake of children and adolescents do not exist in Germany.

In accordance with the DONALD study, surveys with German adults found a decline in fat intake between 
1988 (40 E\%) and 1998 (33-34 E\%) (Mensink et al. 1999). In the MONICA Project Augsburg, the decreased fat intake $(43.5 \mathrm{E} \%$ v. $41.7 \mathrm{E} \%)$ in middle-aged German men was compensated for by an increase in carbohydrate $(40.3$ v. $41.7 \mathrm{E} \%)$ and protein $(16.2$ v. $16.6 \mathrm{E} \%)$ intake between 1984-85 and 1994-95 (Winkler et al. 2000). In a comparison of German data from 1984-85 and 198990 , a decreased consumption frequency of meat, sausages, ham and eggs was noticed, whereas the consumption frequency of cereals, cooked vegetables and mineral water clearly increased (Schaeffler et al. 1996). In the recent German nutrition report (Deutsche Gesellschaft für Ernährung, 2000) favourable dietary modifications are also reported.

Findings in children and adolescents in other industrialized countries also confirm the observed reduction in fat intake in the DONALD study. The comparison between two national representative surveys from the Netherlands (Löwik et al. 1994; Voedingscentrum, 1998) showed a reduction of fat intake from $37.9 \mathrm{E} \%$ in $1987-88$ to 33.8 $\mathrm{E} \%$ in 1998 (mean value for all age-sex groups) and an increased intake of protein $(12.5$ v. $13.5 \mathrm{E} \%)$ and carbohydrates (49.4 E\% v. 52.4 E\%). In the Bogalusa Heart study these trends were also noted between 1973 and 1994 (Nicklas et al. 2001). Swedish adolescents in 1989-90 had a lower fat intake (33 E\%) and a higher carbohydrate intake (52 E\%) compared with previous studies. As in the DONALD study this could be traced back to a decline in intake of fats and oils, and to an increased importance of bread and other cereal products (Bergström et al. 1993). In the course of four representative US surveys between 1965 and 1996, intake of total fat (39 to $32 \mathrm{E} \%$ ) and saturated fatty acids (15 to 12 E\%) decreased. In contrast to the DONALD study, this was due to a decrease in milk intake and an increased consumption of lower fat milks and, in accordance with the DONALD study, of grain-based mixed dishes (Cavadini et al. 2000).

In contrast, in Northumbrian (UK) children fat intake (40 E \%) did not change over a 10-year period from 1980 to 1990 (Adamson et al. 1992).

\section{Anthropometry}

During the 15-year period of the DONALD study we found no increase in the prevalence of overweight and obesity, body weight and BMI. Other authors have reported an increased prevalence of obesity in Germany (KromeyerHauschild et al. 1999), Europe (Martinez, 2000) and the USA (Harlan, 1998). These differences may be due to the stable energy intake of our sample, probably accompanied by a stable activity level (not measured). In addition, comparison of diets of overweight and normal weight subjects showed a higher fat intake in overweight subjects (Garaulet et al. 2000). Therefore, the observed reduction in fat intake $(\mathrm{E} \%)$ in the DONALD study may also have a favourable effect on prevention of adiposity. Adiposity is also negatively correlated with sociodemographic status (Helmert et al. 1997; Martinez et al. 1999). Therefore, the high proportion of upper social class families in the DONALD study sample, as indicated by educational level (Kersting et al. 1998b), might have influenced the prevalence of adiposity. Participants in longitudinal studies such as the DONALD study know their body height and weight, which may possibly counteract adiposity.

\section{Conclusions}

Changes in food choices and nutrient intakes reflect the influences of industry, mass communication, and commercial advertising in our society (Nicklas et al. 1993). Nowadays, the prevention of chronic nutrition-related diseases associated with an affluent diet is in the core of nutrition sciences. This includes a population-based strategy aimed at a fat-modified and fat-reduced diet rich in carbohydrates beginning in childhood. Translated into foodbased dietary guidelines, e.g. the US food pyramid (US Department of Agriculture, 1992) or the German food cycle (Deutsche Gesellschaft für Ernährung, 1991) and the Optimized Mixed Diet, a preventive concept for German children and adolescents (Alexy et al. 2000), these messages have wide dissemination, and their initial success can now be seen in our present study. However, further efforts will be necessary to achieve the preventive recommendations and to stabilize the trend to more favourable dietary habits as documented by the time trends of the DONALD study.

\section{References}

Adamson A, Rugg-Gunn A, Butler T, Appleton D \& Hacket A (1992) Nutritional intake, height and weight of 11-12-yearold Northumbrian children in 1990 compared with information obtained in 1980. British Journal of Nutrition 68, 543-563.

Alexy U, Kersting M \& Sichert-Hellert W (2000) The Optimized Mixed Diet: Evaluation of a food guide system for children and adolescents. Journal of Nutrition Education 32, 94-99.

Barr SI (1993) Secular trends in nutrient intakes of female nutrition students, 1986-1991. Nutrition Research 13, 1099-1103.

Bergström E, Hernell O \& Persson LA (1993) Dietary changes in Swedish adolescents. Acta Paediatrica 81, 472-480.

Canadian Pediatric Society and Health Canada, Joint Working Group (1995) Nutrition recommendations update: dietary fats and children. Nutrition Reviews 53, 367-375.

Cavadini C, Siega-Riz AM \& Popkin BM (2000) US adolescent food intake trends from 1965 to 1996. Archives of Disease in Childhood 83, 18-24.

Cole TJ, Bellizzi MC, Flegal KM \& Dietz WH (2000) Establishing a standard definition for child overweight and obesity worldwide: international survey. British Medical Journal 320, $1-6$.

De Henauw S, Wilms L, Mertens J, Standaert B \& De Backer G (1997) Overall and meal specific macronutrient intake in Belgian primary school children. Annals of Nutrition and Metabolism 41, 89-97.

Department of Health (1989) The Diets of British Schoolchildren. Report on Health and Social Subjects no. 36. London: H.M. Stationery Office.

Deutsche Gesellschaft für Ernährung (1991) Der Mensch ist, was er ißst (You are what you eat). Broschüre. 5 edn. Frankfurt: DGE.

Deutsche Gesellschaft für Ernährung, (editors). (1994) Lebensmittel- und Nährstoffaufnahme in der Bundesrepublik Deutschland (Food Consumption and Nutrient Intake in the Federal 
Republic of Germany). Ernährungsbericht 1992, Ergänzungsband. VERA-Schritenreihe Bd. XII. DGE: Frankfurt.

Deutsche Gesellschaft für Ernährung, (editors) (2000) Ernährungsbericht 2000 (Nutrition Report). DGE: Frankfurt.

European Society for Pediatric Gastroenterology Hepatology and Nutrition, Committee on Nutrition (1994) Committee report: Childhood diet and prevention of coronary heart disease. Journal of Pediatric Gastroenterology and Nutrition 19, 261-269.

Garaulet M, Martinez A, Victoria F, Perez-Llamas F, Ortega R \& Zamora S (2000) Differences in dietary intake and activity level between normal-weight and overweight or obese adolescents. Journal of Pediatric Gastroenterology and Nutrition 30, 253-258.

Goldberg GR, Black AE, Jebb SA, Cole TJ, Margatroyd PR, Coward WA \& Prentice AM (1991) Critical evaluation of energy intake data using fundamental principles of energy physiology: 1. Derivation of cut-off limits to identify underrecording. European Journal of Clinical Nutrition 45, 569-581.

Harlan WR, Landis JR, Flegal KM, Davis CS \& Miller ME (1998) Secular trends in body mass in the United States, 1960-1980. American Journal of Epidemiology 128, $1065-1074$.

Helmert U, Mielck A \& Shea S (1997) Poverty, health, and nutrition in Germany. Reviews on Environmental Health 12, 159-170.

Institute of Medicine (2000) Dietary reference intakes: vitamin C, vitamin E, selenium, carotinoids. Washington, DC: National Academy Press.

Kersting M, Sichert-Hellert W, Alexy U, Manz F \& Schöch G (1998a) Macronutrient intake of 1-18 year old German children and adolescents. Zeitschrift für Ernährungswissenschaft 37, 252-259

Kersting M, Sichert-Hellert W, Lausen B, Alexy U, Manz F \& Schöch G (1998b) Energy intake of 1-18 year old German children and adolescents. Zeitschrift für Ernährungswissenschaft 37, 47-55.

Kromeyer-Hauschild K, Zellner K, Jaeger U \& Hoyer H (1999) Prevalence of overweight and obesity among school children in Jena (Germany). International Journal of Obesity 23, $1143-1150$.

Löwik MRH, Brussard JH, Hulshof KFAM, Kistemaker C, Schafsmaa G, Ockhuizen T \& Hermus RJJ (1994) Adequacy of the diet in the Netherlands in 1987-1988; Dutch nutrition surveillance system. International Journal of Food Sciences and Nutrition 45, Suppl. 1, 1-62.

Marti-Henneberg C, Capdevuka F, Arija V, Perez S, Cuco G, Vizmanos B \& Fernández-Ballart J (1999) Energy density of the diet, food volume and energy intake by age and sex in a healthy population. European Journal of Clinical Nutrition 53, 421 -428.

Martinez JA (2000) Obesity in young Europeans: genetic and environmental influences. European Journal of Clinical Nutrition 54, Suppl. 1, S56-S60.

Martinez JA, Kearney JM, Kafatos A, Paquet S \& Martinez-Gonzalez MA (1999) Variables independently associated with selfreported obesity in the European Union. Public Health Nutrition 2, 125-133.

Mensink GB, Thamm M \& Haas K (1999) Die Ernährung in Deutschland 1998 (Nutrition in Germany 1998). Gesundheitswesen 61, S200-206.
National Research Council (1989) Diet and Health: Implications for Reducing Chronic Disease Risk. Washington, DC: National Academy Press.

Nicklas TA, Elkasabany A, Srinivasan SR \& Berenson G (2001) Trends in nutrient intake of 10-year-old children over two decades (1973-1994): The Bogalusa Heart Study. American Journal of Epidemiology 153, 969-977.

Nicklas TA, Webber LS, Srinivasan SR \& Berenson GS (1993) Secular trends in dietary intakes and cardiovascular risk factors of 10-y-old children: The Bogalusa Heart Study (1973-1988). American Journal of Clinical Nutrition 57, 930-937.

Oja P (1997) Health related physical activity and fitness among European children and adolescents. In: Nutrition and Fitness: Evolutionary Aspects, Children's Health, Programs and Policies [AP Simopoulos, editor]. Basel: Karger, World Review of Nutrition and Dietetics (Series) 81, 98-104.

Schaeffler V, Döring A, Winkler G \& Keil U (1996) Trends in food consumption in a South German population from 1984/ 85 to 1989/90: Results from the WHO MONICA project Augsburg. Annals of Nutrition and Metabolism 40, 129-136.

Schofield WN (1985) Predicting basal metabolic rate, new standards and review of previous work. Human Nutrition:Clinical Nutrition 39, Suppl 1, 5-41.

Sichert-Hellert W, Kersting M \& Manz F (2001) 15-year trends in water intake in German children and adolescents. Results of the DONALD study. Acta Paediatrica 90, 732-737.

Sichert-Hellert W, Kersting M \& Schöch G (1998) Underreporting of energy intake in 1 to 18 year old German children and adolescents. Zeitschrift für Ernährungswissenschaft 37, 242 251.

Souci SW, Fachmann W, Kraut H (1994) Food composition and Nutrition Tables, 5th edn. Stuttgart: Medpharm Scientific Publishing.

Strain JJ, Robson PJ, Livingstone MB, Primrose ED, Savage JM, Cran GW \& Boreham CA (1994) Estimates of food and macronutrient intake in a random sample of Northern Ireland adolescents. British Journal of Nutrition 72, 343-352.

Torun B, Davies PSW, Livingstone MBE, Paolisso M, Sackett R \& Spurr GB (1996) Energy requirements and dietary energy recommendations for children and adolescents $1-18$ years old. European Journal of Clinical Nutrition 50, Suppl 1, S37-S81.

US Department of Agriculture (1992) The Food Guide Pyramid: A Guide to Daily Food Choices. Home and Garden Bulletin no. 252. Washington DC: US Government Printing Office.

Voedingscentrum (1998) Zo eet Nederland. Resultaten van de Voedselconsumptiepeiling 1997-1998 (So Eat Netherlands. Results of the Food Consumption Survey 1997-1998). Den Haag: Voedingscentrum.

World Health Organization (1990a) Prevention in Childhood and Youth of Adult Cardiovascular Disease. Technical Report Series no. 792. Geneva: WHO.

World Health Organization (1990b) Diet, Nutrition and the Prevention of Chronic Diseases. Technical Report Series no. 797. Geneva: WHO.

Winkler G, Döring A \& Keil U (2000) Trends in dietary sources of nutrients among middle-aged men in southern Germany. Results of the MONICA Project Augsburg: dietary surveys 1984/85 and 1994/95. Appetite 34, 37-45. 